TERRORISM AND THE LIBERAL STATE 
By the same author

SOCIAL MOVEMENT

POLITICAL TERRORISM 


\title{
TERRORISM AND THE LIBERAL STATE
}

\author{
PAUL WILKINSON
}




\section{c) Paul Wilkinson 1977}

Softcover reprint of the hardcover 1st edition 1977 978-0-333-19123-1

All rights reserved. No part of this publication may be reproduced or transmitted, in any form or by any means, without permission.

First publisbed 1977 by

THE MACMILLAN PRESS LTD

London and Basingstoke

Associated companies in Delbi Dublin

Hong Kong Jobannesburg Lagos Melbourne

New York Singapore and Tokyo

ISBN 978-0-333-22770-1 ISBN 978-1-349-86153-8 (eBook)

DOI 10.1007/978-1-349-86153-8

This book is sold subject to the standard conditions of the Net Book Agreement.

The paperback edition of this book is sold subject to the condition that it shall not, by way of trade or otherwise, be lent, resold, hired out, or otherwise circulated without the publisher's prior consent in any form of binding or cover other than that in which it is published and without a similar condition including this condition being imposed on the subsequent purchaser. 
For Susan 


\section{CONTENTS}

Prefatory Note

PART I: FORCE, VIOLENCE, ORDER AND THE LIBERAL STATE

I. The Liberal Tradition in Political Philosophy 3

II. The Bases of Political Obligation 12

III. The Rule of Law 16

IV. The Role of Force 18

V. Sanction, Punishment and Deterrence 20

VI. Violence Defined 23

VII. Modes of Conflict, Opposition and Protest 24

VIII. Political Violence: Characteristics and Typology 30

IX. Causes of Political Violence in Liberal States 34

X. Can Political Violence ever be Morally Justified in a Liberal State? 38

XI. The Proper Use of Force in the Liberal State 41

XII. Terror and Terrorism: Concepts, Characteristics and Typology

XIII. Terrorism and Criminality

PART II: INTERNAL TERRORISM AND THE LIBERAL STATE

XIV. The Philosophy of Terror 71

XV. The Terrorist Threat to Liberal Societies $\quad 80$

XVI. The Roots of Terrorism 93

XVII. Terrorist Ideologies and Beliefs 96 
XVIII. Vulnerabilities of Liberal Societies

XIX. Terrorist Strategy and Tactics

Xx. General Problems of Internal Defence against

Terrorism

XXI. General Principles of Counter-terrorist Strategy

XXII. The Role of Intelligence

XXIII. Countering 'Spasm' Terrorism

XXIV. Army's Role in Combating 'Spasm' Terrorism

XXV. Countering Incipient Civil War

PART III: INTERNATIONAL TERRORISM

XXVI. International and Transnational Terrorism

XXVII. Force and Violence in International Relations

XXVIII. International Terrorism and International Relations

XXIX. Underlying Political and Strategic Causes

Xxx. Vulnerabilities: Targets, Technology and Tolerance 188

XXXI. Precipitative Causes

XXXII. Effects of International Terrorism

XXXIII. Potential Threats

XxxIV. The Hijacking Problem

XXXV. Diplomatic Kidnappings and Attacks

XXXVI. Barricade and Hostage Situations

XxxVII. General Measures against International Terrorism 


\section{PREFATORY NOTE}

There have been encouraging signs over the past few years of a growth of scholarly interest in the phenomenon of political terrorism.' Surely it is not entirely coincidence that this has occurred when the incidence of terrorism in many parts of the world has been dramatically increasing. ${ }^{2}$ It has never been my view that it is improper or demeaning for academics to interest themselves in the urgent practical problems of the day. Indeed in discussing the problem of terrorism with members of the public, politicians, officials, members of security forces and fellow academics, one is impressed by the widespread desire for serious analysis and long-term thinking concerning the nature of terrorist phenomena, their causes, effects and policy implications for Western governments and societies. The present book is an attempt to contribute to this analysis and to stimulate further debate through an investigation of the problem of terrorism from a liberal democratic perspective, and to suggest some practicable and effective means of tackling it.

It will come as no surprise to the reader to learn that in the colourful aviary of contemporary Academia many shriek and squawk against any project of this kind. Some, while admitting the fact of terrorism in the contemporary world, want its defenestration from the ivory tower either because of academic snobbery or plain squeamishness. One is reminded of the widespread academic prejudice against war studies. War, like terrorism, is a nasty, bloody, messy business which, some wish to argue, should only be studied by universities under the cacbe sexe of 'Peace' or 'Conflict' studies. Yet another group hold to a position of invincible ignorance about terrorism; they hold that the word has no meaning but is simply a pejorative for freedom fighting or rebellion disapproved of by the authorities. It would be foolish to deny that the word has been abused in this way. For example, the South African government tend to 
designate all those who actively oppose them, by whatever means, as 'terrorists'. But the mere fact of propagandist abuse of a political term surely does not justify dropping it altogether from our vocabulary. Should we drop the word 'democracy' because of the way it has been used by the so-called 'People's Democracies'? Or is the term 'socialist' to be consigned to oblivion because of its appropriation by Hitler's National Socialist party? As I try to make clear in the conceptual discussion in Part I, there are quite clear differentiae between the intent, aims and psychological effects of terrorism and those of other forms of violence such as the collective violence of riots and revolutionary uprisings and conventional war. It is an elementary but common mistake, for example, to equate terrorism with guerrilla war. As a matter of history many guerrilla struggles have been fought without recourse to the tactics of terrorism, and, as will be discussed later, many guerrilla leaders have been explicitly opposed to any policy of terrorisation both on grounds of expediency and morality.

Those who claim to eschew the word 'terrorism' on the grounds that it is contentious and implies value judgement ${ }^{3}$ are by so doing dodging a whole set of issues: (i) they implicitly abandon the essential conceptual basis and framework for analysis of state terror and terroristic agencies and practices; (ii) should we simply ignore the very explicit theorists and manuals prescribing systematic terrorism as a political weapon and spelling out appropriate tactics and techniques?; (iii) what other terms do they suggest we use to differentiate between those governments, political leaders and revolutionaries who do favour and practice such methods from those who do not? It is surely ridiculously ostrich-like to hide our heads from this whole ugly area of historical experience?

A more fundamental opposition is expressed, predictably, by the small groups of anti-liberal democratic intellectuals and ideologues. They often have a sophisticated awareness of the possible political uses of terrorism, and generally offer terrorist movements a promising recruiting ground, a revolutionary ideology or programme and leadership. Even if they do not actually plan and promote acts of terrorism, they are likely to encourage and condone acts of violence, destruction, disruption and intimidation damaging to the liberal democratic system they so loathe. Whereas I may hope to communicate with some sceptical and reflective members of the first group it would be delusive to hope to get through to the hard-core 
allies, apologists and front men of terrorist movements. I suppose it is little use pointing out that 'post-revolutionary' régimes have also proved vulnerable to calculated terrorisation by powerful political and para-military movements or that citizens in 'revolutionary' societies also have basic human needs for security against murder, injury and destruction whether at the hands of the ruling party or its agencies or of private terrorist factions. One can only assume that Communists and their fellow-travellers who remain unmoved by the testimony of The First Circle or The Gulag Archipelago, who cannot or will not listen to the cries of generations of victims of Soviet tyranny, have blotted out all sense of individual rights and freedoms. By suppressing all human feeling or sympathy for individuals in the name of that deadly abstraction, 'revolutionary justice', they have strangled their own humanity.

A main concern of the present work is to try to improve our understanding of the problem of terrorism against the whole background of contemporary international relations and continuing ideological conflict. It is necessary, therefore, to examine the extent to which some, though by no means all, terrorist movements and campaigns are promoted, aided and deployed as auxiliary weapons by revolutionary movements and as modes of unconventional and surrogate war by some states. It will be shown that the Soviet Union has a considerable record of involvement in this type of conflict, and that this has important consequences for Western internal and external defence policy and strategy. However, the reader should be reassured that the author does not seek to present any general conspiracy theory or cold war grand simplification to "explain' contemporary terrorist phenomena. On the contrary, terrorism is a very clear manifestation of the intensifying multipolarity of international conflicts, of the almost infinite variety of actual and potential ideological, religious, ethnic, particularistic, secessionist and international sources of terrorist conflict that beset us. Terrorism is not the monopoly of any ideology or cause; in many countries and circumstances (for example in Italy, Spain, Brazil and Argentina) neo-fascist and ultra-rightist terrorist groups constitute a growing menace. Indeed Mussolini and Hitler can claim the dubious distinction of having pioneered many techniques and tactics of terrorisation as an auxiliary weapon for seizing and consolidating power.

Theorising about political violence and about terrorism in particular raises fundamental and complex ethical issues. Can terrorism 
ever be morally justifiable in an operative liberal democratic society? If not, may it nevertheless be justifiable against totalitarian or authoritarian dictatorships, or against a foreign conqueror? Is there some argument analogous to the case for the 'just war' which may be used to justify terrorist violence under certain circumstances? There are some enormous questions to be posed about the practice of terrorism itself. Should there be some kind of terrorist 'ethic', or rules about the limits of violence that is to be used? Can terrorism be selective, precise and discriminate? Who is to decide, and on what basis are they to decide, who shall be the recipients (victims) of terrorist 'justice'? In liberal democratic societies acute ethical problems arise concerning the appropriate treatment of convicted terrorists who have been attempting through terror to blackmail and intimidate a government, group or community which has majority legitimacy and support into conceding to their political demands. Does their claim to have a political motivation entitle them to special treatment or status in the judicial process? Should the lives of convicted terrorists dedicated to making war on society be forfeit? These are a few of the ethical questions that will be discussed recurrently throughout the present work.

However, there is another kind of theoretical complexity involved. Complexities, ambiguities and uncertainties in the international system, in particular the fluctuating relations between domestic and international political forces, raise baffling problems of empirical theory. Are current trends in terrorism symptomatic of an increasing swing away from bipolarity to multipolarity, and of a relative weakening of super-power capacity to mould international relations? Terrorism can be interpreted as a desperate response of the growing number of weak or powerless groups challenging the rigidities of frontiers, power and resource distribution underpinned by the current international system. A French theorist has asserted 'Terrorism is the weapon of the weak pretending to be strong.' We must go on to ask whether the weak are gaining strength at the expense of the strong or vice versa? Is terrorism, particularly in its international and transnational manifestations, a true harbinger of wider and far more sanguinary and dangerous revolutionary struggles by movements claiming to represent the poor and underprivileged of the Third World against the rich states of the First World? Or, on the other hand, is the very desperation and the fanatical, almost suicidal style of the transnational terrorist 
brotherhoods indicative of their weakness, vulnerability and ultimate political irrelevance? Could they really survive a concerted campaign by the international community to outlaw and eliminate them?

By contrast many indigenous terrorist struggles at regional and national levels are by no means so clearly asymmetrical in character. In some cases (particularly where external powers are acting as their sponsors), revolutionary movements engaging in terrorism may acquire the resources, weapons and popular base equalling or even surpassing the resources of the target régime.

These ambiguities and contradictions should warn us against any premature general theory or model of the causes, inception and development of terrorism. For in reality there are many terrorisms, each calling for different theories, models and approaches from the scholar seeking to relate these phenomena to other dimensions of political change. Therefore the primary tasks must be: to clarify and refine the concept of political terrorism; to establish a working typology of political terrorism; and, most difficult of all, to relate terrorism to other modes of violence and to the basic political values, structures and processes of liberal democracy. These tasks are attempted in Part I of the present work.

Part II, the heart of the book, deals with the special problems of revolutionary and sub-revolutionary political terrorism in liberal democracies. It discusses the underlying and precipitative causes of terrorism in liberal states and assesses influential causal and developmental theories and models of terrorism under these conditions. The ideologies, aims, beliefs, strategies, tactics, organisational structures, recruitment and logistics of terrorist groups are identified and their influence and efficacy are analysed. Considerable attention is given in this section to evaluating both the implications of terrorism for liberal democratic states and the most practicable and potentially effective strategies of prevention, deterrence, internal and external defence and counter-offensive open to governments and security forces. Attention is given to the lessons of recent experience of anti-terrorist campaigns regarding the administrative, police, military and psychological resources, tactics, equipments, security, judicial and political measures most appropriate to the varying intensities of anti-terrorist operations, ranging from isolated bombings and assassinations to major anti-terrorist emergencies. I conclude this section by highlighting what in my 
view are the most serious dangers and mistakes that may threaten the success of anti-terrorist operations by liberal states: under-reaction, political inertia and the disintegration of the state; over-reaction, indiscriminate repression and the loss of popular support and legitimacy.

Liberal democracies are particularly vulnerable to infiltration and attack by international and transnational terrorists and it is with this particular challenge that Part III is concerned. The specific problems of skyjacking, diplomatic kidnappings, embassy attacks and assassinations and possible national, bilateral, regional and international counter-measures and co-operative action against these forms of terrorism are examined.

It will be clear from the foregoing that this book does not offer a general historical narrative of terrorist movements and campaigns, a survey of empirical data or a guide to the literature. Readers should refer elsewhere for these. ${ }^{4}$ My aim has been to concentrate on debating theory, analysis, strategy and policy, and in order to give the main lines of argument sharper definition I have tried to keep cross-references and academic apparatus to an unobtrusive minimum.

The study of terrorism is still relatively new and undeveloped, younger by far than the study of civil violence and revolution. In a field with so few wise men to follow, the contributions of Professors Feliks Gross, Joseph Roucek and Eugene Walter shine like beacons, and all succeeding students of terrorism rest heavily in their debt. I should also like to pay tribute, in this connection, to that pioneering triumvir of British experts on terrorism: Brian Crozier, Robert Moss and Dr Richard Clutterbuck. The superb quality of their contributions is internationally recognised though inadequately acknowledged in British Academia. I wish to thank all three for their generous encouragement, insights and assistance, all of which I have drawn on freely. Shaie Selzer of Macmillan has been remarkable for his patience and kind forbearance. Needless to say, none of the above is responsible for the faults and errors in what follows. 